\title{
Communication \\ Induction of Promoter DNA Methylation Upon High-Pressure Spraying of Double-Stranded RNA in Plants
}

\author{
Athanasios Dalakouras ${ }^{1,2, *(D)}$ and Ioannis Ganopoulos ${ }^{2}$ D \\ 1 Institute of Industrial and Forage Crops, HAO-DEMETER, 41335 Larissa, Greece \\ 2 Institute of Plant Breeding and Genetic Resources, HAO-DEMETER, 57001 Thessaloniki, Greece; \\ giannis.ganopoulos@gmail.com \\ * Correspondence: nasosdal@gmail.com
}

check for updates

Citation: Dalakouras, A.;

Ganopoulos, I. Induction of Promoter DNA Methylation Upon HighPressure Spraying of DoubleStranded RNA in Plants. Agronomy 2021, 11, 789. https://doi.org/ 10.3390/agronomy11040789

Academic Editor: Andrew Eamens

Received: 22 March 2021

Accepted: 7 April 2021

Published: 16 April 2021

Publisher's Note: MDPI stays neutral with regard to jurisdictional claims in published maps and institutional affiliations.

Copyright: (c) 2021 by the authors. Licensee MDPI, Basel, Switzerland. This article is an open access article distributed under the terms and conditions of the Creative Commons Attribution (CC BY) license (https:// creativecommons.org/licenses/by/ $4.0 /)$.
Abstract: Exogenous application of RNA molecules is a potent method to trigger RNA interference (RNAi) in plants in a transgene-free manner. So far, all exogenous RNAi (exo-RNAi) applications have aimed to trigger mRNA degradation of a given target. However, the issue of concomitant epigenetic changes was never addressed. Here, we report for the first time that high-pressure spraying of dsRNAs can trigger de novo methylation of promoter sequences in plants.

Keywords: DNA methylation; promoter; dsRNA; siRNAs; RNAi; bisulfite sequencing

\section{Introduction}

Eukaryotic DNA methylation is an important epigenetic modification governing a broad range of developmental aspects and refers to the addition of a methyl group to the fifth carbon of the six-ring cytosine residue. In plants, de novo DNA methylation is mediated by RNA molecules, thus aptly coined RNA-directed DNA methylation (RdDM) [1]. RdDM is tightly connected to RNA interference (RNAi), likely being its epiphenomenon [2,3]. Briefly, RNAi in plants is initiated by double-stranded RNAs (dsRNAs) that are processed by Dicer-like (DCL) endonucleases into small interfering RNAs (siRNAs), which are loaded into argonaute (AGO) proteins [4]. In general, DCL4 generates 21-nt siRNAs that are loaded onto AGO1 and recognize complementary transcripts for cleavage in the cytoplasm [5,6], while DCL3 generates 24-nt siRNAs that are loaded onto AGO4 and are involved in the RdDM process in the nucleus $[7,8]$. According to the current models, 24-nt siRNAs (canonical RdDM) or even 21/22-nt siRNAs (noncanonical RdDM) interact with the DNA itself or with its nascent transcript produced by RNA polymerase $\mathrm{v}$ (POLV) [9-11]. This interaction is believed to recruit domains-rearranged methyltransferase 2 (DRM2) to de novo methylate the cytosines of the cognate DNA [12]. However, POLV has been suggested to be recruited to an already methylated DNA template [13], thus cannot possibly be involved in the very first step of de novo methylation of a completely unmethylated DNA. Moreover, RdDM was not eliminated in an Arabidopsis thaliana quadruple dcl1 dcl2 dcl3 dcl4 mutant [14], suggesting that DCL-produced siRNAs are dispensable for RdDM. Accordingly, some models propose that the very first step of de novo methylation is triggered not by siRNAs but by long dsRNAs instead $[15,16]$. According to this scenario, dsRNA interacts with cognate DNA and recruits DRM2 to impose a first wave (perhaps incomplete) of methylation marks. To this newly-but-incompletely methylated DNA, POLIV and POLV are recruited. POLIV generates short transcripts $(\sim 40 \mathrm{nt})$ that are further copied by RNA-directed RNA polymerase 2 (RDR2) into $\sim 40 \mathrm{bp}$ dsRNAs [17]. These short POLIV/RDR2 dsRNAs are then processed by DCL3 into 24-nt siRNAs that are loaded onto AGO4 and hybridize with POLV transcript, recruiting once more DRM2 to reinforce/amplify the methylation marks. When the dsRNA-directed de novo and siRNA-directed amplification steps are finished, all cytosines in both strands of the target DNA are methylated in any sequence context: CG, CHG, CHH (H being A, 
$\mathrm{T}$, or C). Upon cell division and in the absence of dsRNAs/siRNAs, $\mathrm{CHH}$ methylation cannot be re-established, thus being the hallmark of de novo RdDM [18]. However, CG and CHG methylation can be mitotically and meiotically maintained even in the absence of dsRNAs/siRNAs by the action of methyltransferase 1 (MET1) [19] and chromomethylase 3 (CMT3) [12], respectively.

Whereas RdDM of (transcribed) coding regions has been routinely achieved by conventional dsRNA-expressing transgenes [20,21], RdDM of (non-transcribed) promoter regions has been more troublesome [22,23]. In general, the most potent inducers of promoter methylation have been transgenes generating either dsRNAs lacking a polyadenylation tail $[24,25]$ or residing in an intron [26]. Both approaches lead to the nuclear localization of the corresponding dsRNAs. However, the use of transgenes and transgenic plants is currently under strict regulation, at least in European Union. Yet, considerable progress over the last decade has suggested alternative methods to trigger RNAi in a transgene-free manner, simply by the exogenous application of dsRNA/siRNA molecules in plants by methods such as foliar spraying, trunk injection, and root drenching [27]. Exogenous RNAi (exo-RNAi) approaches have led to the silencing of plant genes and resistance against a diverse array of pests and pathogens [28-30]. Yet, in all of these cases, the application of dsRNAs/siRNAs aimed to target a given mRNA for degradation, and with a notable exception [28], no study addressed the issue of concomitant epigenetic modifications in the corresponding coding region. What is more, no study so far has analyzed whether exo-RNAi approaches can trigger RdDM of promoter sequences. In this report, we provide clear evidence that spraying of dsRNAs can trigger promoter RdDM in plants.

\section{Materials and Methods}

\subsection{In Vitro Transcription of dsRNA}

In order to generate the template for the in vitro transcription of the dsRNA that would target the $35 \mathrm{~S}$ promoter, PCR was performed using genomic DNA of $N$. benthamiana $16 \mathrm{C}$ and the primers 5-ATA CAG AGT CTC TTA CGA CTC-3 and 5-GTC TTC TTT TTC CAC GAT GCT-3. The occurring $333 \mathrm{bp}$ amplicon was gel excised and used as a template in a subsequent PCR with the T7 promoter-including primers 5-TAA TAC GAC TCA CTA TAG GGA GAA TAC AGA GTC TCT TAC GAC TC-3 and 5-TAA TAC GAC TCA CTA TAG GGA GAG TCT TTT TCC ACG ATG CT-3. Finally, the occurring $379 \mathrm{bp}$ amplicon was used as a template for the generation of the double-stranded RNA with the MEGA Script RNAi kit (ThermoFisher Scientific, www.thermofisher.com, accessed on 15 December 2020), following the manufacturer's instructions.

\subsection{High-Pressure Spraying of $d s R N A$}

Before each spraying application, the dsRNA aliquot was removed from $-80^{\circ} \mathrm{C}$ and diluted with annealing buffer $(1 \times$ working concentration: $60 \mathrm{mM} \mathrm{KCl}, 6 \mathrm{mM}$ HEPES$\mathrm{pH} 7.5,0.2 \mathrm{mM} \mathrm{MgCl} 2$ ), denatured at $70{ }^{\circ} \mathrm{C}$ for $7 \mathrm{~min}$ and re-annealed by being left to cool slowly at room temperature for $1 \mathrm{~h}$. For each plant, a solution of $500 \mu \mathrm{L}$ containing $50 \mu \mathrm{g}$ dsRNA was used for high-pressure spraying ( 8 bar) of 3 leaves to which a small amount of carborundum was merely applied (but not rubbed), so any carborundum-mediated mechanical damage would take place during (and not before) the high-pressure spraying. High-pressure spraying ( 8 bar) conditions were provided by a MicroLux Airbrush Set and a Bormann BAT5060 compressor.

\subsection{Genomic DNA Extraction}

Genomic DNA from N. benthamiana leaves was extracted with a DNEasy Plant Pro kit (Qiagen, www.qiagen.com, accessed on 15 December 2020) according to the manufacturer's instructions. 


\subsection{Bisulfite Sequencing}

Prior to bisulfite reaction, the genomic DNA was fragmented with AseI digestion and cleaned up with phenol/chloroform extraction and ethanol precipitation. The AseIdigested DNA $(1 \mu \mathrm{g} / 20 \mu \mathrm{L})$ was then subjected to bisulfite conversion with the EZ DNA Methylation Gold Kit (Zymo Research, www.zymoresearch.com, accessed on 15 December 2020) according to the manufacturer's instructions. The recovered bisulfite-treated DNA was then subjected to PCR amplification with the degenerate primers 5-AGT YTY AGA YYA AAG GGY AAT-3 and 5-TCT TRC RAA RRA TAR TRR RAT TRT-3 (HPLC-grade purification) and the ZymoTaq Premix (Zymo Research, www.zymoresearch.com, accessed on 15 December 2020) at the gradient temperatures of $46{ }^{\circ} \mathrm{C}, 50{ }^{\circ} \mathrm{C}$, and $54{ }^{\circ} \mathrm{C}$, in order to ensure unbiased amplification of methylated and nonmethylated DNA, as described before [31]. The $327 \mathrm{bp}$ amplicons were pooled together and used for TA-cloning in pGEM T easy vector (Promega, worldwide.promega.com, accessed on 15 December 2020) according to the manufacturer's instruction. For each treatment, 10-12 independent clones were subjected to Sanger sequencing. For the depiction of bisulfite sequencing data of the 279 bp promoter fragment (which occurs when omitting the primer sequences from the 327 bp amplicon), CyMATE software was used (www.cymate.org, accessed on 15 December 2020) [32].

\section{Results and Discussion}

For the dsRNA spraying experiments, we used the Nicotiana benthamiana 16C line (Nb-16C), which harbors the green fluorescent protein (GFP) transgene under the control of Cauliflower Mosaic Virus (CaMV) 35S promoter and nopaline synthase (NOS) terminator [33] (Figure 1a,b). We have previously shown that spraying of siRNA molecules designed to target the GFP coding sequence in $\mathrm{Nb}-16 \mathrm{C}$ triggered local and systemic silencing of the GFP transgene [34]. In this study, we aimed to investigate whether spraying of dsRNA molecules targeting the $35 \mathrm{~S}$ promoter (35S-dsRNA) could trigger RdDM on the cognate sequences. In the promoter region, the $\mathrm{Nb}-16 \mathrm{C}$ contains an $835 \mathrm{bp}$ region of the CaMV, which contains the actual 343 bp promoter sequence (GenBank accession number KY464890) [35]. For 35S-dsRNA spraying, we generated a $333 \mathrm{bp}$ dsRNA designed to target a part of the $343 \mathrm{bp}$ $35 \mathrm{~S}$ promoter by in vitro transcription, covering the essential regions for promoter activity but mapping upstream of the TATA box and the transcriptional start site (TSS) (Figure 1b). In doing so, we ensured that the sprayed dsRNA would target only non-transcribed regions. A recent study showed that exogenous application of RNA molecules is greatly affected by conditions such as plant age, soil moisture, and time of application [36]. In our case, $\mathrm{Nb}-16 \mathrm{C}$ plants were grown in standard conditions in a growth chamber $(16 \mathrm{~h} / 8 \mathrm{~h}$ light/dark photoperiod, $25{ }^{\circ} \mathrm{C}, 67 \%$ humidity). Six-leaf stage plants were used for all spraying experiments, which were conducted early in the morning. In each plant, the abaxial surface (approximately 1-2 cm diameter) of 3 leaves was sprayed with the $333 \mathrm{bp}$ 35S-dsRNA. The 'control' plants were sprayed with the annealing buffer into which the 35S-dsRNA was dissolved. 
(a) Spraying of in vitro-transcribed 333 bp dsRNA (8 bar, $50 \mu \mathrm{g}$ )

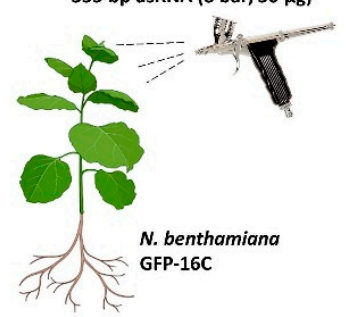

(c)

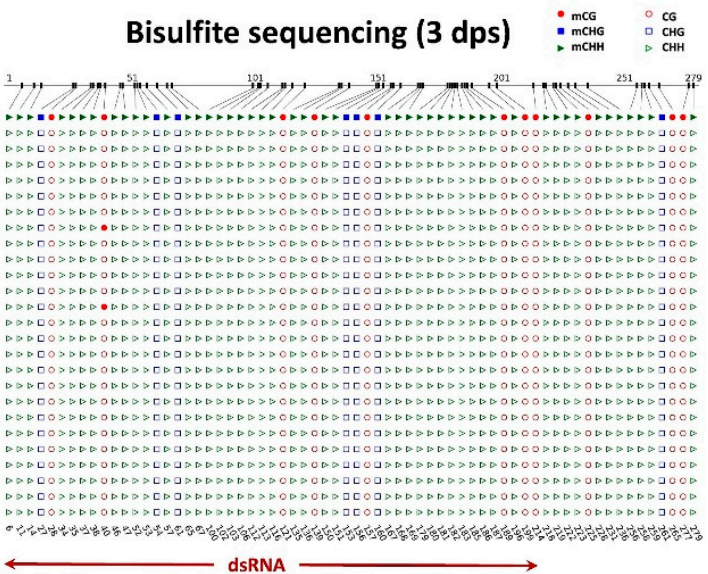

(b)

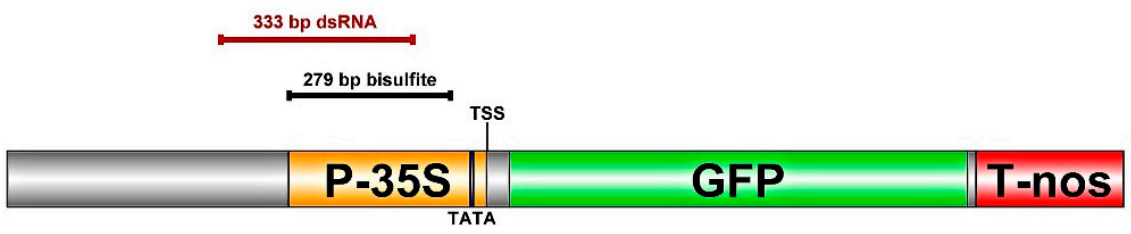

(d)

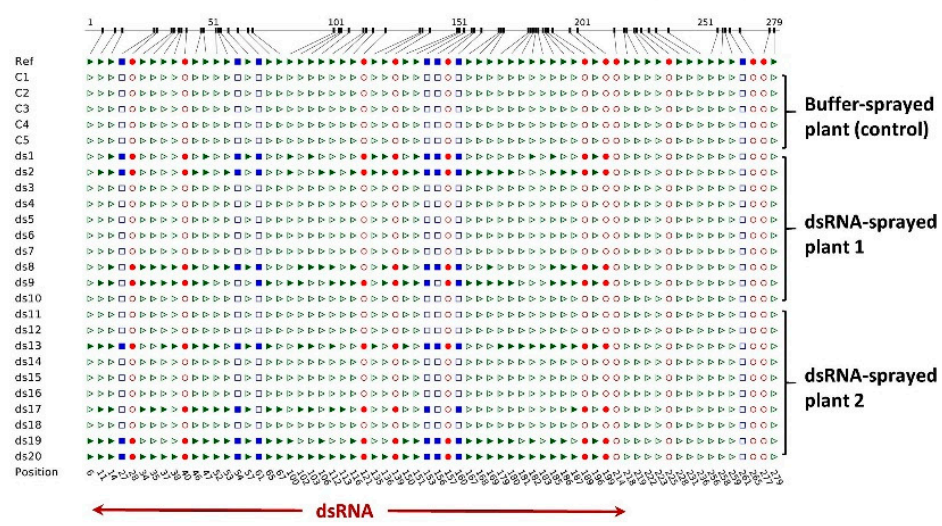

Figure 1. Analysis of promoter methylation upon high-pressure spraying of double-stranded RNAs (dsRNA). (a) Green fluorescent protein (GFP)-expressing Nicotiana benthamiana plants (line 16C, Nb-16C) were sprayed with 333 bp dsRNA. (b) Schematic representation of the transgene present in Nb-16C, depicting the Cauliflower Mosaic Virus (CaMV) $35 \mathrm{~S}$ promoter (P-35S), the GFP coding region, and the nopaline synthase terminator (T-NOS). The TATA motif and the transcriptional start site (TSS) are indicated. The dsRNA (333 bp) mapping region is indicated in the red line and the region chosen for bisulfite sequencing ( $279 \mathrm{bp}$ ) with the black line. (c) Bisulfite sequencing data at $3 \mathrm{dps}$. (d) Bisulfite sequencing data at $10 \mathrm{dps}$. The data represent sequenced clones ( 5 clones for control plants, 10 clones for each of the two plants). Circles denote cytosines in the CG context, squares denote cytosines in CHG context and triangles denote cytosines in CHH context. Empty symbols refer to nonmethylated cytosine, whereas filled symbols to methylated cytosine. Bisulfite analysis was performed with CyMATE software.

We chose to perform a time course analysis of the methylation status of the $35 \mathrm{~S}$ promoter at 3- and 10-days post spraying (dps). At each of these timepoints, the sprayed tissue of each plant was pooled and used for DNA extraction and DNA methylation analysis by bisulfite sequencing. Treatment of DNA with sodium bisulfite results in the conversion of nonmethylated cytosine to uracil, and during PCR amplification, the uracil is replaced by thymine. Thus, sequences of PCR products from bisulfite-treated DNA exhibit thymines for nonmethylated cytosines. Bisulfite sequencing allows for strand-specific detection of DNA methylation, and we chose to analyze a $279 \mathrm{bp}$ part of the upper strand of the $35 \mathrm{~S}$ promoter (Figure $1 \mathrm{~b}$ ). When analyzing tissue obtained at $3 \mathrm{dps}$, no methylation of the $35 \mathrm{~S}$ promoter was detected (Figure 1c). This suggested that, at least, the region we analyzed did not display inherent features rendering it resistant to bisulfite treatment and that the $35 \mathrm{~S}$ promoter did not display any methylation prior to dsRNA-spraying. However, when we analyzed tissue obtained $10 \mathrm{dps}$, bisulfite sequencing revealed the onset of significant methylation of the $35 \mathrm{~S}$ promoter (Figure 1d). However, not all bisulfite clones showed methylation. Almost $60 \%$ of the clones were completely devoid of methylation, while $40 \%$ of the clones exhibited very dense cytosine methylation marks at CG, CHG, and $\mathrm{CHH}$ context, in both plants 1 and 2 (Figure 1d). The reasons underlying this stark difference in methylation are not clear, but it is likely that the methylated clones (40\%) reflect DNA retrieved from cells that efficiently received the dsRNA, whereas the others $(60 \%)$ not. It has been shown that in contrast to siRNA spraying, long dsRNA spraying is less efficient [37]. We thus hypothesize that a significant portion of the dsRNA remained on 
the leaf surface and/or the leaf apoplast and that only a few dsRNA molecules managed to be efficiently delivered inside the plant cell. Moreover, the dsRNAs would need to be transported to the nucleus to trigger RdDM. Thus, despite the huge amount of dsRNA sprayed on each plant $(50 \mu \mathrm{g})$, perhaps only a small fraction of these molecules managed to finally reach the nucleus of a limited number of cells. Nevertheless, it is of interest that in the methylated clones $(40 \%)$, the methylation pattern was restricted to the region defined by the dsRNA and did not spread towards the $3^{\prime}$ (Figure 1d), as observed in other cases [38]. The $3^{\prime}$ spreading of methylation involves the concerted action of POLIV and RDR2, but it is not clear how rapid this process is. The gradual onset of unavoidable mechanical damage imposed upon the sprayed tissue $10 \mathrm{dps}$ did not allow us to continue our analysis to subsequent time points (e.g., $20 \mathrm{dps}$ or beyond). Thus, we could not analyze whether $3^{\prime}$ spreading of methylation would eventually take place.

In this short communication, we show for the first time that dsRNA spraying triggers de novo methylation of a promoter sequence in plants. These perhaps preliminary data are nevertheless important, given the complete absence of similar reports on epigenetic phenomena induced upon exo-RNAi applications. Future research should elucidate the mechanistic details underlying our observations, e.g., investigating whether the dsRNA was processed by DCLs into siRNAs (small RNA deep sequencing), and if yes, what size class of siRNAs was generated and whether they homogeneously covered the dsRNA region and fully matched the regions of methylation. Additional insights would be provided by analyzing whether such putative DCL processing takes place in the cytoplasm or in the nucleus where DCLs seem to co-localize [39], as well as whether other intermediate dsRNA molecules (besides siRNAs) are formed that may have a role in the whole process, as shown before [40]. Finally, dsRNA-spraying in $d c l$ knockout plants and/or 24-nt siRNA spraying and subsequently evaluating their ability to trigger methylation could provide valuable insights on the still elusive mechanism of RdDM.

In a more applied context, our data suggest that dsRNA spraying could potentially serve as a useful tool in epigenetics-based crop breeding platforms [41,42]. DNA methylation of promoter sequences ensues histone modifications, such as $\mathrm{H} 3 \mathrm{~K} 9$ methylation and $\mathrm{H} 3 / \mathrm{H} 4$ deacetylation, that result in transcriptional gene silencing (TGS) [43,44]. Indeed, when certain criteria are met (see below), plants sprayed with dsRNAs against a promoter sequence may exhibit RdDM and TGS. Since, in plants, gametes are formed from somatic cells, in the sprayed-free progeny, CG/CHG methylation and perhaps even TGS (depending on the promoter) can be maintained. It needs to be noted, though, that, in our case, we did not observe TGS (absence of GFP fluorescence upon ultraviolet lamp detection) in $3 \mathrm{dps}$ or even at $10 \mathrm{dps}$. In some cases, dense RdDM and concomitant TGS may require up to 4 generations of the continuous presence of the dsRNA trigger to be established $[23,45]$. However, optimization of dsRNA spraying assays may reach the desired goal. Such optimizations could include (i) the development of methods for efficient dsRNA delivery in meristematic tissues, which give rise to all developing plant organs and gametes, not just in easily sprayable plants, such as $A$. thaliana and N. benthamiana, but also in agronomically more important crops, (ii) the conjugation of dsRNAs with nanoparticles, such as clay nanosheets [46], so as to increase dsRNA delivery inside the plant cell, (iii) importantly, the introduction of nucleus-localization RNA signals, such as the C/D box motif [47], in the dsRNA (e.g., in the spacer of hairpin RNAs), so as to increase dsRNA delivery in the nucleus, and (iv) the consideration of tandem dsRNA spraying across 3-4 consecutive generations in order to increase the likelihood for efficient RdDM and TGS. If so, one could envisage that dsRNA spraying targeting endogenous sequences in various crops could lead to trans-generationally maintained DNA methylation and even TGS. This aspect is of particular interest in classical breeding programs that suffer from the loss of genetic variation (genetic erosion) [48]. Resorting to the epigenome and modifying it in a specific and transgene-free method by exo-RNAi approaches could reveal the much needed cryptic diversity that could invigorate breeding platforms. For reasons that are not very clear, endogenous promoters are not as prone to RdDM/TGS as transgenic 
promoters are [22,49]. However, several endogenous promoters, especially tissue- and organ-specific ones, are susceptible to RdDM/TGS [3,50-53] and can be considered for the aforementioned approaches.

Author Contributions: Conceptualization, A.D.; experiments, A.D.; resources, A.D. and I.G.; data interpretation, A.D. and I.G.; writing-original draft preparation, A.D.; writing-review and editing, A.D. and I.G.; funding acquisition, I.G. All authors have read and agreed to the published version of the manuscript.

Funding: This research was funded by European Regional Development Fund (ERDF), through the Operational Program "Southern Aegean" 2014-2020, entitled "Enhancement of quality and nutritional traits of Naxos potatoes using omics-technologies. GrEaTest-Potatoes" (NAIГ1-0040991).

Conflicts of Interest: The authors declare no conflict of interest.

\section{References}

1. Wassenegger, M.; Heimes, S.; Riedel, L.; Sänger, H.L. RNA-directed de novo methylation of genomic sequences in plants. Cell 1994, 76, 567-576. [CrossRef]

2. Jones, L.; Hamilton, A.J.; Voinnet, O.; Thomas, C.L.; Maule, A.J.; Baulcombe, D.C. RNA-DNA Interactions and DNA Methylation in Post-Transcriptional Gene Silencing. Plant Cell 1999, 11, 2291-2301. [CrossRef] [PubMed]

3. Sijen, T.; Vijn, I.; Rebocho, A.; van Blokland, R.; Roelofs, D.; Mol, J.N.; Kooter, J.M. Transcriptional and posttranscriptional gene silencing are mechanistically related. Curr. Biol. 2001, 11, 436-440. [CrossRef]

4. Fusaro, A.F.; Matthew, L.; Smith, N.; Curtin, S.J.; Dedic-Hagan, J.; Ellacott, G.; Watson, J.M.; Wang, M.; Brosnan, C.; Carroll, B.J.; et al. RNA interference-inducing hairpin RNAs in plants act through the viral defence pathway. EMBO Rep. 2006, 7, $1168-1175$. [CrossRef]

5. Hamilton, A.J.; Baulcombe, D.C. A species of small antisense RNA in posttranscriptional gene silencing in plants. Science 1999, 286, 950-952. [CrossRef]

6. Baumberger, N.; Baulcombe, D.C. Arabidopsis ARGONAUTE1 is an RNA Slicer that selectively recruits microRNAs and short interfering RNAs. Proc. Natl. Acad. Sci. USA 2005, 102, 11928-11933. [CrossRef]

7. Chan, S.W.-L.; Zilberman, D.; Xie, Z.; Johansen, L.K.; Carrington, J.C.; Jacobsen, S.E. RNA Silencing Genes Control de Novo DNA Methylation. Science 2004, 303, 1336. [CrossRef]

8. Zilberman, D.; Cao, X.; Jacobsen, S.E. ARGONAUTE4 Control of Locus-Specific siRNA Accumulation and DNA and Histone Methylation. Science 2003, 299, 716-719. [CrossRef] [PubMed]

9. Matzke, M.A.; Kanno, T.; Matzke, A.J. RNA-Directed DNA Methylation: The Evolution of a Complex Epigenetic Pathway in Flowering Plants. Annu. Rev. Plant Biol. 2015, 66, 243-267. [CrossRef]

10. Matzke, M.A.; Mosher, R.A. RNA-directed DNA methylation: An epigenetic pathway of increasing complexity. Nat. Rev. Genet. 2014, 15, 394-408. [CrossRef]

11. Gallego-Bartolomé, J. DNA methylation in plants: Mechanisms and tools for targeted manipulation. New Phytol. 2020, 227, 38-44. [CrossRef]

12. Cao, X.; Aufsatz, W.; Zilberman, D.; Mette, M.; Huang, M.S.; Matzke, M.; Jacobsen, S.E. Role of the DRM and CMT3 Methyltransferases in RNA-Directed DNA Methylation. Curr. Biol. 2003, 13, 2212-2217. [CrossRef] [PubMed]

13. Liu, Z.-W.; Shao, C.-R.; Zhang, C.-J.; Zhou, J.-X.; Zhang, S.-W.; Li, L.; Chen, S.; Huang, H.-W.; Cai, T.; He, X.-J. The SET Domain Proteins SUVH2 and SUVH9 Are Required for Pol V Occupancy at RNA-Directed DNA Methylation Loci. PLoS Genet. 2014, 10, e1003948. [CrossRef]

14. Yang, D.-L.; Zhang, G.; Tang, K.; Li, J.; Yang, L.; Huang, H.; Zhang, H.; Zhu, J.-K. Dicer-independent RNA-directed DNA methylation in Arabidopsis. Cell Res. 2016, 26, 1264. [CrossRef] [PubMed]

15. Dalakouras, A.; Papadopoulou, K.K. Epigenetic Modifications: An Unexplored Facet of Exogenous RNA Application in Plants. Plants 2020, 9, 673. [CrossRef]

16. Dalakouras, A.; Wassenegger, M. Revisiting RNA-directed DNA methylation. RNA Biol. 2013, 10, 453-455. [CrossRef] [PubMed]

17. Zhai, J.; Bischof, S.; Wang, H.; Feng, S.; Lee, T.-F.; Teng, C.; Chen, X.; Park, S.Y.; Liu, L.; Gallego-Bartolome, J.; et al. A One Precursor One siRNA Model for Pol IV-Dependent siRNA Biogenesis. Cell 2015, 163, 445-455. [CrossRef] [PubMed]

18. Pelissier, T.; Thalmeir, S.; Kempe, D.; Sanger, H.L.; Wassenegger, M. Heavy de novo methylation at symmetrical and nonsymmetrical sites is a hallmark of RNA-directed DNA methylation. Nucleic Acids Res. 1999, 27, 1625-1634. [CrossRef] [PubMed]

19. Aufsatz, W.; Mette, M.F.; Matzke, A.J.M.; Matzke, M. The role of MET1 in RNA-directed de novoand maintenance methylation of CG dinucleotides. Plant Mol. Biol. 2004, 54, 793-804. [CrossRef]

20. Dadami, E.; Dalakouras, A.; Zwiebel, M.; Krczal, G.; Wassenegger, M. An endogene-resembling transgene is resistant to DNA methylation and systemic silencing. RNA Biol. 2014, 11, 934-941. [CrossRef]

21. Křižová, K.; Depicker, A.; Kovařík, A. Epigenetic switches of tobacco transgenes associate with transient redistribution of histone marks in callus culture. Epigenetics 2013, 8, 666-676. [CrossRef] 
22. Okano, Y.; Miki, D.; Shimamoto, K. Small interfering RNA (siRNA) targeting of endogenous promoters induces DNA methylation, but not necessarily gene silencing, in rice. Plant J. 2008, 53, 65-77. [CrossRef]

23. Zilberman, D.; Cao, X.; Johansen, L.K.; Xie, Z.; Carrington, J.C.; Jacobsen, S.E. Role of Arabidopsis ARGONAUTE4 in RNADirected DNA Methylation Triggered by Inverted Repeats. Curr. Biol. 2004, 14, 1214-1220. [CrossRef]

24. Mette, M.F.; Aufsatz, W.; Van Der Winden, J.; Matzke, M.A.; Matzke, A.J.M. Transcriptional silencing and promoter methylation triggered by double-stranded RNA. EMBO J. 2000, 19, 5194-5201. [CrossRef] [PubMed]

25. Mette, M.; Van Der Winden, J.; Matzke, M.; Matzke, A. Production of aberrant promoter transcripts contributes to methylation and silencing of unlinked homologous promoters in trans. EMBO J. 1999, 18, 241-248. [CrossRef] [PubMed]

26. Dalakouras, A.; Moser, M.; Zwiebel, M.; Krczal, G.; Hell, R.; Wassenegger, M. A hairpin RNA construct residing in an intron efficiently triggered RNA-directed DNA methylation in tobacco. Plant J. 2009, 60, 840-851. [CrossRef]

27. Dalakouras, A.; Wassenegger, M.; Dadami, E.; Ganopoulos, I.; Pappas, M.L.; Papadopoulou, K. Genetically Modified OrganismFree RNA Interference: Exogenous Application of RNA Molecules in Plants. Plant Physiol. 2020, 182, 38-50. [CrossRef]

28. Dubrovina, A.S.; Aleynova, O.A.; Kalachev, A.V.; Suprun, A.R.; Ogneva, Z.V.; Kiselev, K.V. Induction of Transgene Suppression in Plants via External Application of Synthetic dsRNA. Int. J. Mol. Sci. 2019, 20, 1585. [CrossRef]

29. Fletcher, S.J.; Reeves, P.T.; Hoang, B.T.; Mitter, N. A Perspective on RNAi-Based Biopesticides. Front. Plant Sci. $2020,11,51$. [CrossRef]

30. Taning, C.N.T.; Arpaia, S.; Christiaens, O.; Dietz-Pfeilstetter, A.; Jones, H.; Mezzetti, B.; Sabbadini, S.; Sorteberg, H.; Sweet, J.; Ventura, V.; et al. RNA-based biocontrol compounds: Current status and perspectives to reach the market. Pest Manag. Sci. 2020 76, 841-845. [CrossRef] [PubMed]

31. Clark, S.J.; Statham, A.; Stirzaker, C.; Molloy, P.L.; Frommer, M. DNA methylation: Bisulphite modification and analysis. Nat. Protoc. 2006, 1, 2353-2364. [CrossRef] [PubMed]

32. Hetzl, J.; Foerster, A.M.; Raidl, G.; Scheid, O.M. CyMATE: A new tool for methylation analysis of plant genomic DNA after bisulphite sequencing. Plant J. 2007, 51, 526-536. [CrossRef]

33. Voinnet, O.; Baulcombe, D.C. Systemic signalling in gene silencing. Nat. Cell Biol. 1997, 389, 553. [CrossRef] [PubMed]

34. Dalakouras, A.; Wassenegger, M.; McMillan, J.N.; Cardoza, V.; Maegele, I.; Dadami, E.; Runne, M.; Krczal, G.; Wassenegger, M. Induction of Silencing in Plants by High-Pressure Spraying of In vitro-Synthesized Small RNAs. Front. Plant Sci. 2016, 7, 1327. [CrossRef]

35. Philips, J.G.; Naim, F.; Lorenc, M.T.; Dudley, K.J.; Hellens, R.P.; Waterhouse, P.M. The widely used Nicotiana benthamiana 16c line has an unusual T-DNA integration pattern including a transposon sequence. PLoS ONE 2017, 12, e0171311. [CrossRef]

36. Kiselev, K.V.; Suprun, A.R.; Aleynova, O.A.; Ogneva, Z.V.; Dubrovina, A.S. Physiological Conditions and dsRNA Application Approaches for Exogenously induced RNA Interference in Arabidopsis thaliana. Plants 2021, 10, 264. [CrossRef]

37. Uslu, V.V.; Bassler, A.; Krczal, G.; Wassenegger, M. High-Pressure-Sprayed Double Stranded RNA Does Not Induce RNA Interference of a Reporter Gene. Front. Plant Sci. 2020, 11, 534391. [CrossRef]

38. Daxinger, L.; Kanno, T.; Bucher, E.; Van Der Winden, J.; Naumann, U.; Matzke, A.J.M.; Matzke, M. A stepwise pathway for biogenesis of 24-nt secondary siRNAs and spreading of DNA methylation. EMBO J. 2008, 28, 48-57. [CrossRef]

39. Pontes, O.; Vitins, A.; Ream, T.S.; Hong, E.; Pikaard, C.S.; Costa-Nunes, P. Intersection of Small RNA Pathways in Arabidopsis thaliana Sub-Nuclear Domains. PLoS ONE 2013, 8, e65652. [CrossRef]

40. Boutla, A.; Kalantidis, K.; Tavernarakis, N.; Tsagris, M.; Tabler, M. Induction of RNA interference in Caenorhabditis elegans by RNAs derived from plants exhibiting post-transcriptional gene silencing. Nucleic Acids Res. 2002, 30, 1688-1694. [CrossRef] [PubMed]

41. Tirnaz, S.; Batley, J. Epigenetics: Potentials and Challenges in Crop Breeding. Mol. Plant 2019, 12, 1309-1311. [CrossRef]

42. Varotto, S.; Tani, E.; Abraham, E.; Krugman, T.; Kapazoglou, A.; Melzer, R.; Radanović, A.; Miladinović, D. Epigenetics: Possible applications in climate-smart crop breeding. J. Exp. Bot. 2020, 71, 5223-5236. [CrossRef]

43. Matzke, M.; Aufsatz, W.; Kanno, T.; Daxinger, L.; Papp, I.; Mette, M.; Matzke, A.J. Genetic analysis of RNA-mediated transcriptional gene silencing. Biochim. Biophys. Acta (BBA) Gene Struct. Expr. 2004, 1677, 129-141. [CrossRef] [PubMed]

44. Wassenegger, M. The Role of the RNAi Machinery in Heterochromatin Formation. Cell 2005, 122, 13-16. [CrossRef]

45. Fischer, U.; Kuhlmann, M.; Pecinka, A.; Schmidt, R.; Mette, M.F. Local DNA features affect RNA-directed transcriptional gene silencing and DNA methylation. Plant J. 2008, 53, 1-10. [CrossRef]

46. Mitter, N.; Worrall, E.A.; Robinson, K.E.; Li, P.; Jain, R.G.; Taochy, C.; Fletcher, S.J.; Carroll, B.J.; Lu, G.Q.M.; Xu, Z.P. Clay nanosheets for topical delivery of RNAi for sustained protection against plant viruses. Nat. Plants 2017, 3, 16207. [CrossRef]

47. Samarsky, D.A.; Fournier, M.J.; Singer, R.H.; Bertrand, E. The snoRNA box C/D motif directs nucleolar targeting and also couples snoRNA synthesis and localization. EMBO J. 1998, 17, 3747-3757. [CrossRef]

48. Gallusci, P.; Dai, Z.; Génard, M.; Gauffretau, A.; Leblanc-Fournier, N.; Richard-Molard, C.; Vile, D.; Brunel-Muguet, S. Epigenetics for Plant Improvement: Current Knowledge and Modeling Avenues. Trends Plant Sci. 2017, 22, 610-623. [CrossRef] [PubMed]

49. Fischer, R. Breeding wheat for increased potential yield: Contrasting ideas from Donald and Fasoulas, and the case for early generation selection under nil competition. Field Crop. Res. 2020, 252, 107782. [CrossRef]

50. Eamens, A.; Wang, M.-B.; Smith, N.A.; Waterhouse, P.M. RNA Silencing in Plants: Yesterday, Today, and Tomorrow. Plant Physiol. 2008, 147, 456-468. [CrossRef] [PubMed] 
51. Cigan, A.M.; Haug-Collet, K.; Clapp, J. Transcriptional silencing of heterologous anther promoters in maize: A genetic method to replace detasseling for seed production. Plant Reprod. 2014, 27, 109-120. [CrossRef] [PubMed]

52. Cigan, A.M.; Unger-Wallace, E.; Haug-Collet, K. Transcriptional gene silencing as a tool for uncovering gene function in maize. Plant J. 2005, 43, 929-940. [CrossRef] [PubMed]

53. Heilersig, B.H.J.B.; Loonen, A.E.H.M.; Janssen, E.M.; Wolters, A.-M.A.; Visser, R.G.F. Efficiency of transcriptional gene silencing of GBSSI in potato depends on the promoter region that is used in an inverted repeat. Mol. Genet. Genom. 2006, 275, 437-449. [CrossRef] [PubMed] 